ENTREVISTA 



\section{“É bom massacrar índio no país"}

Entrevista de Rosivaldo Ferreira da Silva (cacique Babau) a Daniela Fernandes Alarcon Aldeia Serra do Padeiro, Terra Indígena Tupinambá de Olivença, maio 2014

Resumo: Nesta entrevista, realizada em maio de 2014 na aldeia Serra do Padeiro (Terra Indígena Tupinambá de Olivença, sul da Bahia), o cacique Babau (Rosivaldo Ferreira da Silva) discorre sobre a história de expropriação e resistência dos Tupinambá. Nela, evidencia-se a concepção territorial indígena, para quem a terra pertence a entidades não humanas conhecidas como encantados, foi construída pelos antepassados e é condição de possibilidade de vida autônoma.

Palavras-chave: Tupinambá, povos indígenas, território, retomadas de terras

Resumen: En esta entrevista, que se llevó a cabo en mayo de 2014 en la aldeia Serra do Padeiro (Tierra Indígena Tupinambá de Olivença, sur de Bahia, Brasil), el cacique Babau (Rosivaldo Ferreira da Silva) recuenta la historia de expropiación y resistencia de los Tupinambá. La narrativa evidencia la concepción territorial indígena, según la cual la tierra pertenece a entidades no humanas conocidas como encantados, fue construida por los ancestros y es condición de posibilidad de vida autónoma.

Palabras-clave: Tupinambá, pueblos indígenas, territorio, recuperación de tierras

Abstract: In this interview, held on May 2014 in the Serra do Padeiro village (Tupinambá de Olivença Indigenous Territory, in the south of Bahia, Brazil), chief Babau (Rosivaldo Ferreira da Silva) tells the history of expropriation and resistance of the Tupinambá people. The narrative expresses the Indigenous conception of territory, according to which the land belongs to non-human entities called encantados, was built by the ancestors and is the condition of possibility for autonomous life.

Keywords: Tupinambá, Indigenous peoples, territory, recovery of lands

Em maio de 2012, os Tupinambá da aldeia Serra do Padeiro - localizada no extremo oeste da Terra Indígena ( $\mathrm{TI}$ ) Tupinambá de Olivença, que se estende por porções dos municípios de Buerarema, Ilhéus e Una, no sul da Bahia - retomaram parte do conjunto de fazendas genericamente conhecido como Unacau. Criada em 1978, valendo-se de mecanismos de expropriação territorial disseminados na região e de financiamento público, a Unacau Agrícola S.A. rapidamente tornou-se uma das maiores produtoras de cacau do país, até declinar, no final da década 
de 1980, em decorrência do avanço da vassoura-de-bruxa. Quando os indígenas ocuparam a área, eu estava em campo - pesquisava, justamente, as retomadas de terra. ${ }^{1}$ Em definição sucinta, pode-se dizer que as retomadas são processos de recuperação, pelos indígenas, de áreas por eles tradicionalmente ocupadas, no interior da TI Tupinambá de Olivença, e que se encontravam em posse de não índios.

O processo de demarcação da TI teve início em 2004. Em 2009, a Fundação Nacional do Índio (Funai) delimitou uma área de cerca de 47 mil ha. Após a publicação do relatório de identificação e delimitação da TI, teve lugar a etapa conhecida como "contraditório", quando o órgão indigenista, por determinação do Decreto ${ }^{\circ}$ 1775/1996, deve analisar as contestações à regularização da TI. No caso tupinambá, todas foram indeferidas. O processo foi encaminhado, então, para o ministro da Justiça, José Eduardo Cardozo, que deveria assinar a portaria declaratória da TI. Porém, violando os prazos legais, Cardozo não a publicou até agora. Nesse quadro, os indígenas mobilizaram-se para recuperar seu território. Entre 2004 e 2012, os Tupinambá da Serra do Padeiro retomaram 22 fazendas; em 2013, o processo acelerou-se e, hoje, somam-se cerca de 70 áreas retomadas apenas nessa aldeia. A despeito de violentas tentativas de reintegração de posse e prisões de lideranças, os indígenas mantiveram-se em posse de todas as áreas. Nelas, voltaram a se dedicar às atividades que desenvolviam tradicionalmente (agricultura em pequena escala, criação de animais, caça, pesca e coleta), atualizando seus vínculos identitários, minando relações de dominação/sujeição com não índios e contribuindo para a recuperação ambiental.
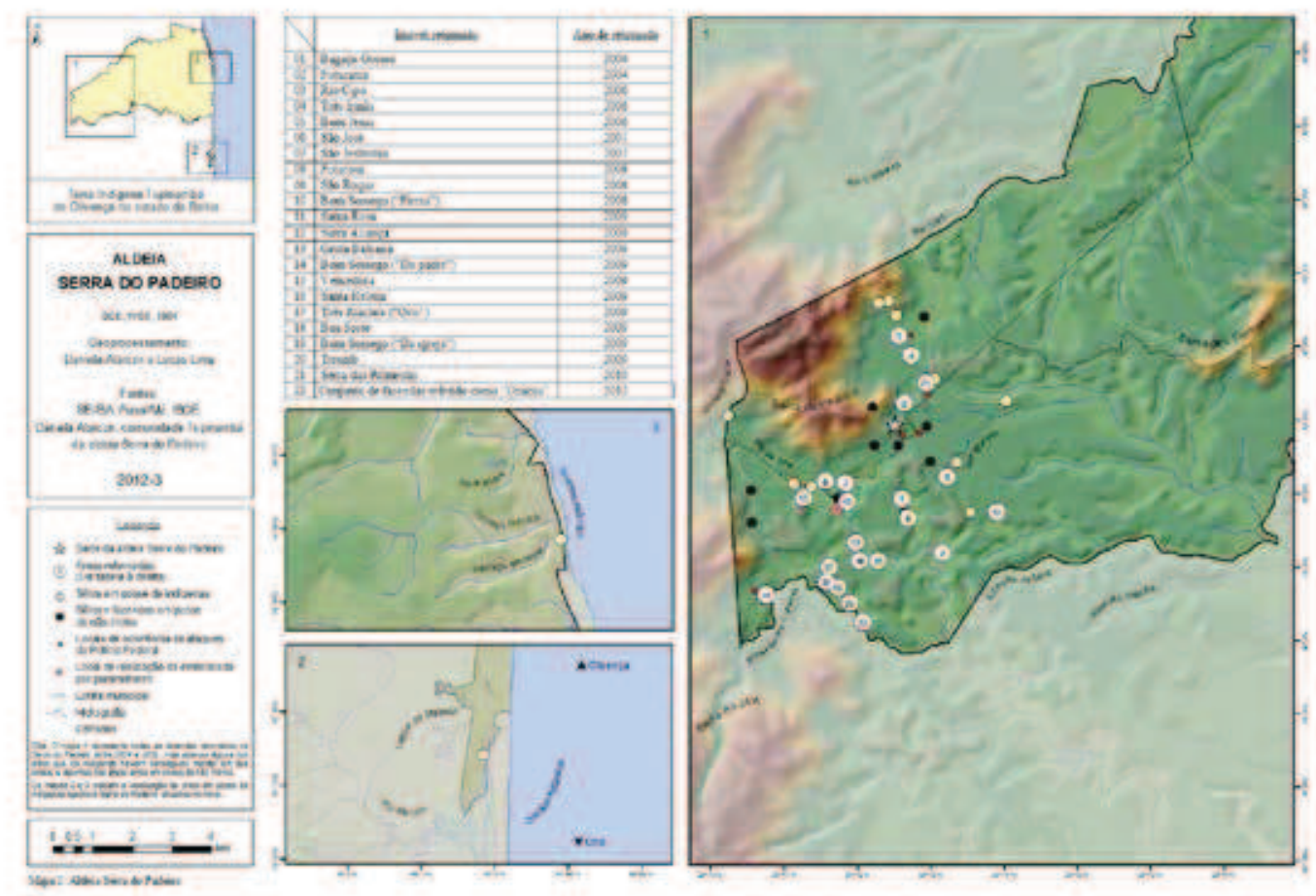

Dois anos depois da ação de retomada a que me referi há pouco, em maio de 2014, encontrava-me novamente na Unacau - desta vez, para gravar uma longa entrevista com o cacique Babau (Rosivaldo Ferreira da Silva), principal liderança da aldeia Serra do Padeiro. Estava às voltas com a realização de um documentário

1 ALARCON, Daniela Fernandes. "O retorno da terra: As retomadas na aldeia Tupinambá da Serra do Padeiro, sul da Bahia”. (Dissertação de mestrado em Ciências Sociais, Universidade de Brasília, 2013). 
de curta-metragem sobre a história de expropriação e resistência dos Tupinambá, que buscaria narrá-la da perspectiva dos indígenas. A entrevista que se segue é uma versão quase integral do diálogo com Babau. ${ }^{2}$ Nela, fica evidente a concepção territorial dos Tupinambá da Serra do Padeiro, para quem a terra pertence aos encantados (entidades não humanas centrais na sua cosmologia), foi construída pelos antepassados e é condição de possibilidade de vida autônoma.

Passagens da história dos Tupinambá que se tornaram marcos da memória do grupo pontuam a narrativa do cacique Babau. Remontando ao período colonial, ele recorda um conhecido episódio da "pacificação dos índios" no sul da Bahia, o massacre do Cururupe. Em 1559, a praia de mesmo nome, extremo norte da TI Tupinambá de Olivença, foi cenário de um sangrento ataque contra os indígenas que ali habitavam, comandado por Mem de Sá. Segundo relato do próprio governador-geral, os corpos dos indígenas assassinados, dispostos lado a lado na praia, estendiam-se por cerca de uma légua. A reconstrução operada por Babau evoca também a escravização nos engenhos de açúcar; o recrutamento de indígenas do sul da Bahia para lutar na Guerra do Paraguai; o avanço da fronteira agrícola, em fins do século XIX, impulsionado pela cacauicultura; massacres que tiveram lugar já no tempo do cacau; e estratégias expropriatórias largamente utilizadas, como a medição obrigatória de terras, a concessão de títulos de posse a não índios e a tomada de terras em decorrência de dívidas contraídas pelos indígenas, na maioria das vezes, no quadro de um sistema de aviamento.

Três figuras fundamentais para a compreensão da história de expropriação e resistência dos Tupinambá da Serra do Padeiro emergem do depoimento. A primeira delas, Manoel Pereira de Almeida, referido como doutor Almeida, foi o principal responsável pela penetração de não índios no território indígena durante as primeiras décadas do século XX. Nascido em São Félix, na Bahia, em 1880, Almeida formou-se engenheiro agrônomo, em Salvador, em 1904. Após se mudar para a região sul da Bahia, atuou inicialmente como topógrafo na Delegacia de Terras de Canavieiras e terminou à frente da administração de Una, de 1919 a 1937, mantendo influência na região até a década de 1960. Referido pelos indígenas como o "dono de Una" ou o "dono dos direitos", foi, em sua época, o maior proprietário rural da área. Nas narrativas indígenas, Almeida figura ao lado de outros chefes políticos locais, juízes, agentes da repressão, pretensos proprietários de terras e jornalistas da imprensa hegemônica, para explicar a violência de que os Tupinambá foram e continuam sendo vítimas.

As duas outras personagens, Marcellino José Alves e João de Nô (João Ferreira da Silva) - este último, avô de Babau -, figuram no polo oposto a Almeida. Entre os últimos anos da década de 1920 e o fim da década de 1930, teve lugar a chamada "revolta do caboclo Marcellino". Na época, membros da elite local tencionavam construir uma ponte sobre o rio Cururupe - como se indicou, limite norte da $\mathrm{TI}$-, facilitando o acesso à área, desde a sede de Ilhéus. Com o intuito de barrar o avanço de não índios sobre suas terras, Marcellino mobilizou os indígenas. Em decorrência disso, foi perseguido e preso seguidas vezes. Reportagens da época dão conta dos confrontos armados que tiveram lugar no interior do território tupinambá e deixam ver a construção da imagem de Marcellino como um facínora. Seu paradeiro após 1937 é desconhecido.

Com a derrota de Marcellino e seus companheiros, teve início um período extremamente difícil para os Tupinambá. As investidas dos não índios recrudescer-

2 Sou grata a Vânia Moreira pelo convite para publicá-la neste dossiê. 
am, os indígenas estavam invisíveis para além das fronteiras regionais e tiveram de pôr em prática intrincadas estratégias para não perder seu território de todo. Muitos tiveram de partir, mas outros tantos ficaram, prensados em pequenos sítios, enfrentando cotidianamente a violência dos não índios. São lembrados até hoje como mourões, as estacas grossas que sustentam a cerca, como aqueles que, ficando, permitiram que outros retornassem. É o caso de João de Nô. Rezador afamado, profetizava o retorno da terra - o tempo em que uma praga se abateria sobre os cacaueiros e o território, libertado das fazendas, tornaria aos indígenas. Em seu leito de morte, em 1981, João de Nô legou aos descendentes a missão de "segurar a terra". Três de seus netos - entre os quais, Babau - foram incumbidos de "aprender a cultura do branco", para defender o território. E foi justamente estudando, em Santa Cruz Cabrália, que Babau travou contato com o movimento indígena do extremo sul da Bahia, por ocasião das mobilizações que antecederam o massivo protesto realizado em 2000, em contraponto à comemoração dos 500 anos de "descobrimento" do Brasil. Na vigência da Constituição de 1988, o contexto era outro, permitindo que Babau e lideranças tupinambá de outras partes do território articulassem suas demandas por direitos territoriais em face do Estado.

Nesta entrevista, conhecemos a luta dos Tupinambá pelo retorno da terra da boca de alguém que tem tido sua identidade étnica sistematicamente negada, que tem sua cabeça a preço e que permaneceu cinco meses encarcerado, inclusive em uma penitenciária de segurança máxima. Alguém profundamente entusiasmado com as retomadas de terras, que vêm permitindo o retorno dos indígenas dispersos, dos bichos e dos encantados, que, em decorrência da penetração dos não índios, haviam recuado. "Tudo, tudo voltou."

No que diz respeito à apresentação da entrevista, ainda que informações oriundas de fontes bibliográficas e documentais (periódicos, inquéritos policiais, processos judiciais e administrativos, entre outros) pudessem ser entrelaçadas à fala de Babau, detalhando algumas passagens, escolhi realizar o mínimo de intervenções possível. Observações entre colchetes e notas de rodapé foram empregadas apenas quando considerei estritamente necessário. Em minha avaliação, o discurso de Babau é denso e articulado, de modo que não valeria sacrificar sua fluidez. Note-se que o depoimento foi transcrito conforme os padrões da norma culta e que, apesar de no campo da antropologia etnônimos serem convencionalmente grafados sem declinação de número, optei por manter nas respostas de Babau, conforme ocorreram, as formas Tupinambá e Tupinambás. 


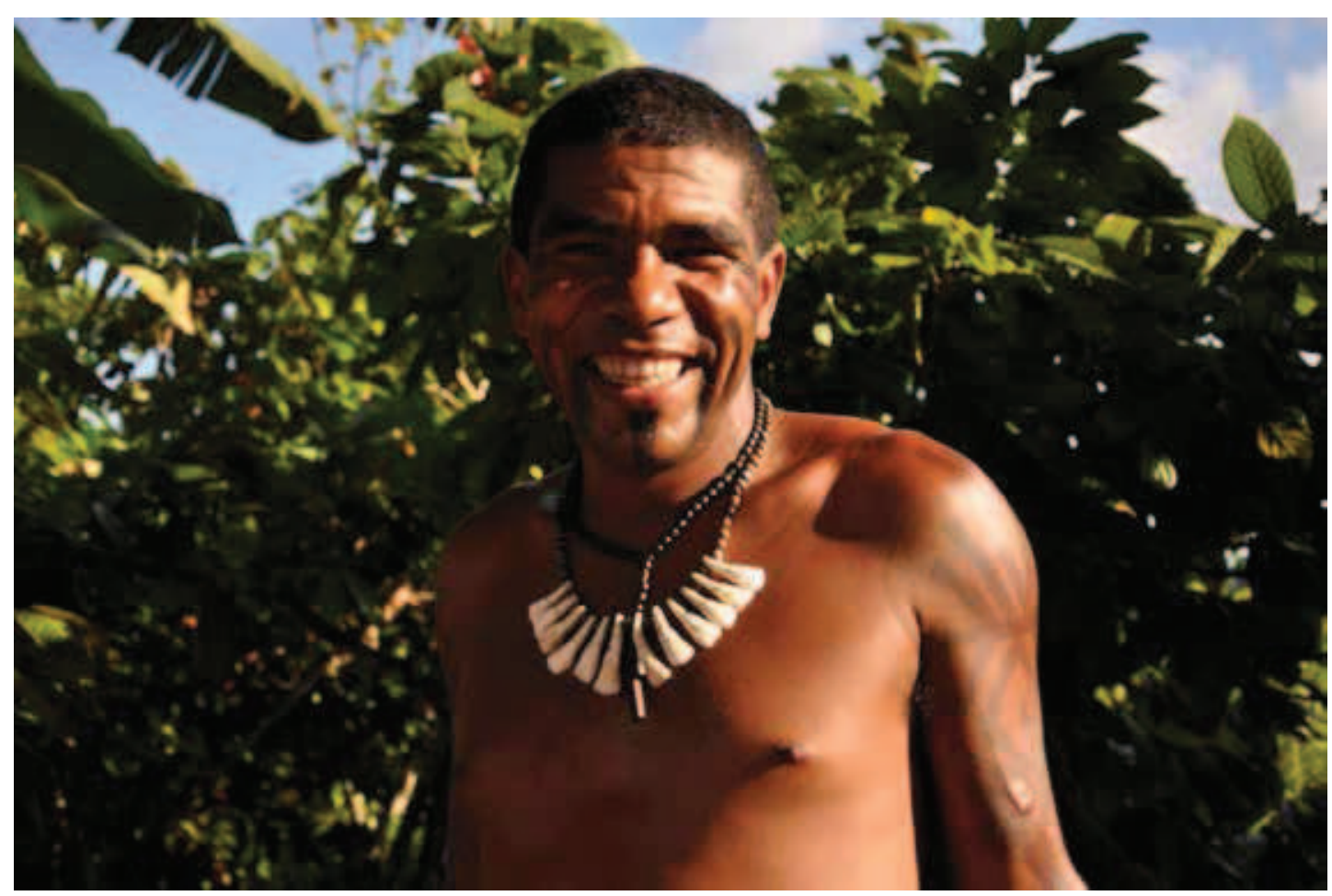

Cacique Babau (Rosivaldo Ferreira da Silva), principal liderança da aldeia Serra do Padeiro. Por Daniela Alarcon, 18 jan. 2012.

\section{Daniela Fernandes Alarcon - Como se deu a entrada dos "brancos" na terra tupi- nambá?}

Cacique Babau - A chegada do cacau na região foi que motivou muito a invasão das terras da gente, porque antes eles [não índios] não tinham tanto interesse, porque era serra, montanha, então nós estávamos mais preservados. [...] Apesar de que aqui, na região da serra, eles não conseguiram tomar pé, não conseguiram ocupar - a ocupação veio muito depois. [...] Quando o cacau disseminou bem na região e viram a importância da terra boa daqui dessa região, começaram os confrontos diretos por causa da terra e relacionados ao cacau. E aí começou. O próprio doutor Almeida começou a distribuir as nossas terras - ele era o delegado de terras de Una - para quem quisesse ampliar os plantios, fazer esses plantios mais organizados. Ele era o responsável por distribuir as terras e tirar os índios daqui e mandar ou para o aldeamento de Santa Rosa ou para a terra dos índios, que é Monte Pascoal. ${ }^{3}$ Então, ele era o responsável direto pela retirada dos índios da região, ele foi o responsável direto pela distribuição das terras. [...] Ele era o delegado supremo, ele mandava aqui no sul da Bahia na questão terra. [...] E ele tinha uma ligação muito forte com as oligarquias regionais. As grandes áreas de terra, era ele que media. E tinha dois agrimensores sob jurisdição dele, o Paulo Badaró e o Vitorio Badaró, que eram os responsáveis por medir... e ele expulsar quem estivesse, né? Então, criar os títulos de terra, tudo... eram eles os responsáveis. [...] A ordem que ele desse, era essa que era válida. Então, ele chegava e dizia: "Ó, vocês têm que ir embora, vocês estavam aqui, mas vocês não são donos, essa terra é de fulano”. E se a pessoa dissesse que não, que não saía, então mor-

3 A área referida por Babau como aldeamento Santa Rosa situa-se no que hoje corresponde à Reserva Indígena (RI) Caramuru Catarina-Paraguaçu, habitada pelos Pataxó Hã-Hã-Hãe e próxima à TI Tupinambá de Olivença. Já o Monte Pascoal situa-se no extremo sul da Bahia, em território Pataxó, expropriado pelo Estado com a criação do Parque Nacional do Monte Pascoal. 
ria. Ele que cuidava da limpeza total da terra também, de deixar sem ninguém dentro. Aliás, os títulos de terras daqui são todos dessa época. [...] Então, muita gente, famílias foram mortas, muitas famílias foram expulsas sem direito a nada, muitos índios foram transferidos ilegalmente e as terras foram... [...] Muitas terras aqui que a gente ocupa, [onde] os índios produzem, os caras, os familiares [dos pretensos proprietários]: "Não, mas nós somos donos". Nunca estiveram aqui. [...] E tinha essa questão de compras na cidade. Então, eles tinham local de venda de alimentação, de tudo, e as famílias compravam fiado; depois, eles tomavam as terras. Muitos perderam terra assim. [...] Então, [doutor Almeida] é um cara que foi muito perverso. Ele fez atrocidades aqui, enormes. Tudo a mando do governo, né? Que ele era do governo.

\section{DFA - E como o doutor Almeida ficou conhecido na memória oficial?}

CB - Ah, como o homem que alavancou a região, o homem que trouxe a prosperidade. É um cidadão acima da lei, porque fazia parte da oligarquia corrupta que existe até hoje aqui, né?

\section{DFA - Você pode falar mais sobre as perseguições e os massacres que os Tupi- nambá sofreram ao longo da história?}

CB - Desde a chegada dos portugueses - foi em 1501 aqui em llhéus, né? -, começaram os principais confrontos [com indígenas]. [...] Depois começou a escravização dos índios para o plantio da cana-de-açúcar, e criaram os principais engenhos na região. Escravizaram. E então começaram os processos de libertação: os índios da floresta iam libertar os outros, que estavam presos. Os índios se organizaram, quebraram engenhos e libertaram os índios que estavam mantidos cativos. [...] O massacre do Cururupe ficou famoso, mas, fora esse massacre, teve centenas de outros, depois desse massacre, muitos outros surgiram. Então, o massacre do Cururupe foi o mais expressivo e documentado, né? Ficou documentado. [...] E eles começaram os massacres através de doenças. Começaram a disseminar a varíola, a catapora e várias outras doenças que levaram a outro massacre generalizado. [...]. Ou seja, foi um genocídio programado e organizado dentro do país, e que permanece até hoje. Ele não deixou de acontecer. Mas nós conseguimos sobreviver. [...] Então, depois disso aí, tem um massacre, que é mais acentuado assim, que foi no final do século 19, aqui na aldeia das Tabocas, que fica aqui no rio Una, no final da aldeia da gente, onde fica a Reserva Biológica de Una. Tudo é área nossa. Até hoje tem o cemitério chamado Cemitério dos Sem Registro, que foi onde mataram... como ninguém tinha [registro], os brancos deram esse nome, Sem Registro. Na história, não existem esses massacres. Existe o cemitério, todo mundo conhece as histórias, o cemitério tem nome, o Cemitério dos Sem Registro. [...] Também tem a questão da Guerra do Paraguai, né? Que também sofreu uma baixa significativa, o povo Tupinambá. Porque tem até registro na câmara dos vereadores de Ilhéus, que deixa bem claro que ia substituir a levada dos filhos dos coronéis, que foram convocados, por indígenas. Os juízes de Ilhéus, tudo, vieram ao aldeamento convocar os índios para ir para a Guerra do Paraguai. ${ }^{4}$ E pelo que os velhos sabem - os velhos contam, mas não se encontra

4 Aqui, ao falar em aldeamento, Babau refere-se à vila de Olivença, hoje distrito de Ilhéus, situado parcialmente no interior da TI Tupinambá de Olivença. Antigo aldeamento jesuítico de Nossa Senhora da 
isso documentado -, foi feita uma proposta para a gente receber uma sesmaria de terra. Vários foram para a guerra, alguns retornaram, outros não retornaram. Mas os que retornaram, quando chegaram aqui, não encontraram o direito à terra, encontraram perseguição pura.

\section{DFA - Depois dessa época, o próximo grande enfrentamento travado pelos Tupi- nambá se deu com o caboclo Marcellino, né? Você pode falar sobre ele?}

CB - Em Olivença... eles [os não índios] queriam criar um centro turístico em Olivença e precisavam ter o controle da cidade. [...] Olivença sempre teve as águas sagradas. Quem tomava banho, não ficava com ferida no corpo, curava todas as feridas, fazia bem. Então, todos queriam estar ali em Olivença para tomar banho das águas. [...] Então, isso é o que eles queriam: eles queriam ter acesso àquilo que faz bem ao índio. [Os não índios pensavam:] "Nós temos dificuldade para ocupar aquela região, porque... atravessar os manguezais, atravessar o rio Cururupe, atravessar esses negócios. Nós precisamos alavancar a região, construir pontes". E aí começa a história de Marcellino. Quando começa a construção dessa ponte, aí começam as principais brigas, porque os índios não concordam em trazer... porque sabiam que a construção da ponte ia facilitar ainda mais a entrada dos não índios na região. [...] Aí a briga começou. Para construir essa ponte, gerou um conflito muito grande. Aí apareceu a figura do Marcellino como um dos principais líderes dos Tupinambás. Ele desponta como alguém que vai contra esse avanço dentro do território e consegue organizar uma quantidade considerável de índios que concorda a mesma coisa com ele e fazem um enfrentamento. [...] Ele cobra a atuação... ele começa a fazer os enfrentamentos. Então, nesse período, começa a ser difamado, os coronéis da região começam a difamá-lo na mídia. Primeiro na mídia. [Chamavam-no de] Todos os tipos de nome: ele é o Lampião do sul da Bahia, é o bugre, é o caboclo que virou selvagem. [...] E aí eles começam a utilizar, como é hoje, a mídia para criminalizar. Nesse mesmo período, começam a utilizar a mídia e criticar, e Marcellino sofre algumas prisões. Sofre uma prisão, sofre outra prisão, aí depois ele vem para as matas, mantém a luta, vai para Caramuru, os Pataxó se unem também à luta. Mas esse período foi um período muito turbulento, de muito massacre, muita morte... [...] Aí depois vem essa acusação, que a mídia toda divulgava, de que era um grupo de comunistas. [...] E aí o ataque foi mortal, como é hoje. Imagina esse ataque que fazem à minha pessoa, no tempo de Marcellino, que foi da mesma proporção ou pior. Hoje, para mim, não está sendo pior, porque conseguimos muitos aliados. [...] Então as volantes [policiais] eram... eles ocuparam no período a Serra do Padeiro e Serra das Trempes - como é o Exército hoje aqui. Aí daqui a 70 anos eles vão negar que o Exército esteve aqui, como negam hoje [que a polícia esteve no tempo de Marcellino]. Eles negam que naquele tempo as volantes viviam aqui $24 \mathrm{~h}$, fazendo ataque dentro da Serra do Padeiro e Serra das Trempes, perseguindo Marcellino e todos os índios que aqui viviam, que eles chamavam de arruaceiros... era tanto apelido que eles davam aos familiares da gente que aqui viviam... [...] Então, sempre foi o governo, sempre foi a polícia, sempre foi o Judiciário que tentou nos eliminar, eliminar os Tupinambás. Então é massacre até chegar aos dias de hoje, não tem intervalo, não tem parada. Só não são divulgados.

Escada, a vila seguiu sendo, até a primeira metade do século 20, majoritariamente habitada por indígenas. 
DFA - Após o desaparecimento de Marcellino, a correlação de forças ficou muito desfavorável aos Tupinambá, certo? Como se deu o processo que levaria, já nos anos 2000, ao reconhecimento oficial da Terra Indígena Tupinambá de Olivença?

CB - Veja bem, nós, por causa dos massacres anteriores... foram tantos, que ficamos quase sem guerreiros. Não tinha como tocar a segurada do território. [...] E nós sempre... os encantados cobravam, mandaram a gente recuar e manter terra, mas que chegaria a época de a gente voltar a lutar pelo território todo, rever o território da terra. E nós ficamos anos, gerações, só fazendo rituais, ouvindo, na época, que eles autorizariam o retorno. [...] Quando chega um período antes de vovô morrer, perto de ele falecer, ele... os encantados chegam e pedem para que eu, Jurandir [Ferreira da Silva], que é Baiaco, meu irmão, e Magnólia [Jesus da Silva], minha irmã... [Ele] chamou nós três e disse que nós, índios, só tínhamos perdido as terras todas porque nós não tínhamos também o conhecimento que o branco tinha. [...] Então, como a gente não conhecia o que eles conheciam, nós éramos facilmente enganados. Então, [ele disse] que nós teríamos as funções de estudar, adquirir o conhecimento do branco, para que quando chegasse a época de lutar, a gente também tivesse o conhecimento para manter a luta e garantir a terra e não perder mais. Então a gente cumpriu a nossa parte. [...] Eu era novinho, eu estava apenas com oito anos de idade, sete a oito anos de idade quando eu recebi essa ordem. [...] E aí, nós fomos estudar em escola de branco, aprender tudo, e os encantados sempre na... e foi outro período turbulento também aqui, porque vovô faleceu, então os fazendeiros todos da região quiseram tomar o restante das terras nossas. Então foi um período conturbadíssimo, um período de morte... [...] E aí o certo é que os encantados orientaram que nesse período a gente não saísse, a gente se mantivesse, que o período de a gente lutar seria outro momento. Nós ficamos... para garantir as terras que a gente tinha, nós não podíamos sair. [...] E aí nós conseguimos passar esse período turbulento. Em 95, começam os pequenos grupos a questionar, a conversar com o pessoal de Caramuru, o pessoal do extremo sul... e eu estudando, nessa época, lá em [Santa Cruz] Cabrália, com os meninos lá, movimentando, com a Comissão Brasil Outros 500, conversando com todo mundo. E aí com a Funai [Fundação Nacional do Índio] já atuando, o Cimi [Conselho Indigenista Missionário], Funai, todo mundo já ouvindo. [...] No ano 2000, aí surge a declaração oficial dos Tupinambás. ${ }^{5}$ [...] Então, nesse período aqui, do ano 2000, aí começa, de fato, a luta. E aí foi quando nós, aqui na Serra do Padeiro... os encantado nos autorizaram a iniciar a luta ininterrupta, ou seja, ou vivem ou morrem todos, mas a terra tem que sair. E pronto. Os encantados ordenaram e disseram: "É a última batalha". Então, aí iniciamos e vamos até o final.

\section{DFA - Quem são os encantados?}

CB - É toda força da natureza, para resumir [risos]. [...] Os encantados, para nós, são a ligação direta entre nós e deus, Tupã. [...] Porque, para nós, Tupã foi quem criou tudo. E nos criou. Mas ele precisa conversar com a gente e precisa dar informação para nós e saber informação de nós. E para ter esse elo, ele deixou os

5 O reconhecimento oficial dos Tupinambá pelo Estado brasileiro deu-se em 13 de maio de 2002, por meio de nota técnica da Coordenação Geral de Estudos e Pesquisas da Funai (CGEP/Funai). Note-se que, à época, o Brasil ainda não adotara a Convenção 169 da Organização Internacional do Trabalho (OIT), que determina a autoidentificação como critério de reconhecimento de grupos indígenas. 
encantados, que falam com ele e falam com a gente, trazem o que ele quer de nós e levam o que nós queremos dele. Então, nós conversamos sempre. Se nós adoecemos, nós mandamos os encantados pedirem qual é o remédio que nos sara. Se a gente está com muita guerra, como é que faz para a gente ganhar a guerra, como é que faz para manter? Se nós estamos escassos de alimento, como é que faz para melhorar a alimentação? O que é que a gente deve fazer? Tudo é consultado aqui. Então, é por isso que eles representam tudo. [...] Então, tem os encantados que comandam os ventos, tem os encantados que comandam as águas, o que comanda as pedras, o que comanda a floresta, o que comanda o mar. Ou seja, tem o grupo de encantados para cada coisa que existe na natureza. [...] Tudo funcionando interligadamente. [...] E nós ouvimos cada um, para quando a gente mexer em uma coisa, não ofender a outra. Então, por isso que eu falo: os encantados são a força da natureza. [...] Nossa terra... nós nunca podemos sair da Serra [do Padeiro], nós temos que permanecer e lutar, vencer ou morrer aqui. [...] Então, o território, ele não é simplesmente um território, ele é sagrado. Por que a igreja católica tem o Monte Sião, que é onde Davi... deus falava com todos os outros? É sagrado. A gente sabe que ali, para aquele povo, é a origem de deus na terra. E nós também temos: é a Serra. [...] Aqui é um ponto sagrado para nós, religiosamente, então o território é religioso. Nós vivemos para cuidar da terra, que é dos encantados. E nós estamos aqui para zelar e não podemos nos corromper, na corrupção dos povos estrangeiros que nos cercam. Nós temos que viver dignamente, sem medo de morrer. E você vê que a gente não tem. [...] E que nada tira a felicidade da gente. Porque nossa terra é uma terra sagrada. [...] Nós temos uma terra que é... para realmente contemplar todos aqueles que morreram, foram assassinados e não tiveram um lugarzinho de descanso na vida, porque todos os seus territórios estão ocupados. Não tiveram direito aos rituais corretos de seus povos para a transição de uma vida para outra. Foram violados todos os direitos dos povos indígenas no país. [...] O massacre no Brasil, o genocídio no Brasil, é generalizado e não para. O problema é que não estamos... é que o país não reconhece o genocídio.

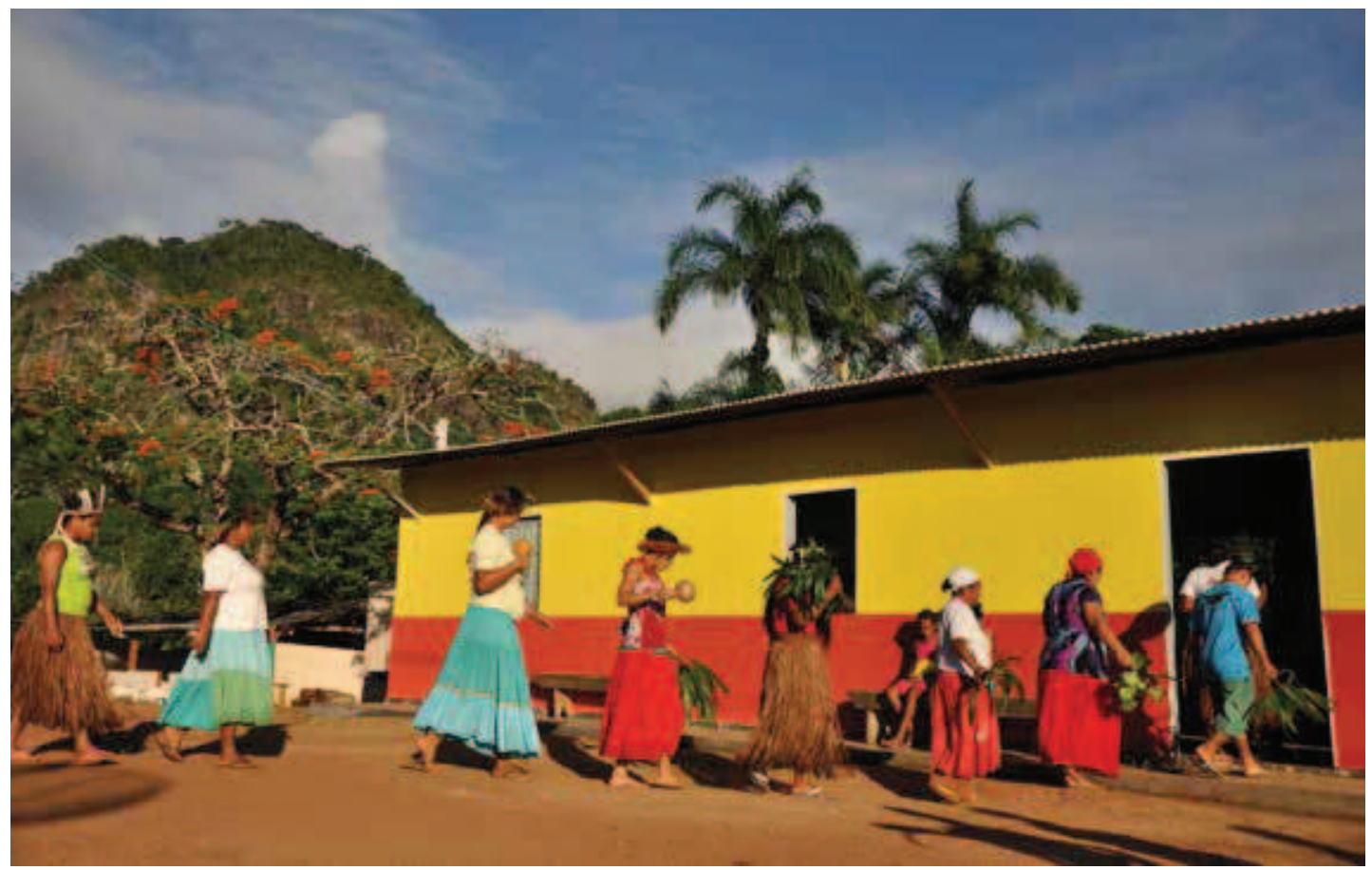

Indígenas retornando da mata com ramos para enfeitar a casa do santo para a festa de São Sebastião, na aldeia Serra do Padeiro.

Por Daniela Alarcon, 18 jan. 2012. 
DFA - Desde que iniciaram o processo de recuperação do território, vocês passaram a ser intensamente criminalizados. Você, por exemplo, foi preso.

CB - Não só uma vez. Marcellino já foi preso... foi preso três vezes. E eu já fui preso três vezes. Marcellino, na última vez, foi morto. ${ }^{6}$ Eu, pelo menos, da última vez, ainda não fui - mas era para me matarem. Inclusive, quando eu estava preso em Brasília [em 2014], lá na cidade de Buerarema, fizeram festa. Festejaram e contaram aos quatro ventos: "Agora nós eliminamos". [...] Tinham tudo acertado para quando chegar... ter a minha execução, e ser apenas uma morte de presídio, que nem nos outros cantos aí, que eliminam as pessoas dizendo que é guerra interna dentro do presídio. [...] Eu sou ameaçado de morte, não só por fazendeiros, mas pela própria força policial do governo. Quem orquestra todas as questões para cima de nós aqui é a polícia, junto com os fazendeiros e, até que se prove o contrário, com o apoio maciço dos juízes locais, tanto estaduais quanto federais. E a imprensa é que faz a opinião pública apoiar a decisão deles. Então, isso aqui é uma questão orquestrada. A polícia chega e assume: "Eu faço, desde que a opinião publica esteja...”. [...] Porque no Brasil eles já descobriram uma coisa: bote na imprensa, convença o povo, deixe estar que no Judiciário vai ser condenado. "Pode ser inocente, mas nós condenamos, porque a imprensa é quem define.” Então, isso é grave. Isso é muito grave, porque uma imprensa corrupta, que nem nós temos hoje no país, uma imprensa que desde o tempo da ditadura... servia à ditadura e agora serve aos ditadores, porque a ditadura só mudou de face, ela continua implantada no país, porque nós não temos uma democracia, a democracia é só para quem tem dinheiro. [...] Então, essa imprensa está servindo à concentração de terra no país, essa imprensa está servindo à corrupção no país e à criminalização dos pobres e dos movimentos sociais. Então, se ela serve para isso, ela não deveria exercer função, porque ela é um poder de convencimento em massa. [...] E é o que está fazendo em cima de nós aqui. Então, nós, Tupinambás, aparecemos sempre com a discriminação em alta, como assassinos, ladrões, falsos índios, supostos índios. Cacique... eu sou o Lampião do sul da Bahia, assassino em série, bandido, invasor, ladrão de terra, sequestrador, assassino... todo tipo de perfil ruim é atribuído a nós, Tupinambás.

\section{DFA - E também tem havido repressão, por parte do Estado, e ações violentas organizadas por pessoas e grupos contrários à demarcação.}

CB - Até hoje, aqui, desde o ano 2000, quando se iniciaram as lutas, até agora, nenhuma morte aqui na Serra do Padeiro. Agora, o pessoal tem matado muita gente na região de Olivença; nas outras aldeias, tem morrido gente para caramba [...] E só quem morre é índio, né? Engraçado que as balas aqui têm uma direção certa. É índio. E o assassino nunca é o fazendeiro. [...] Aí foi vindo Força Nacional [de Segurança Pública], PM [Polícia Militar], [Polícia] Civil, Polícia Rodoviária Federal, Polícia Federal, mais a Força Nacional e mais o Exército. Olha! [...] O que eu sei é que colocaram a polícia para fazer um amedrontamento geral do povo Tupinambá, para ver se o povo recuava, [para que] não mantivesse a reivindicação da terra e aceitasse a negociação

6 Em 1937, após notícia sobre a libertação de Marcellino, que fora preso pela terceira vez, os arquivos silenciam sobre seu paradeiro. Em campo, conheci diversas versões formuladas pelos indígenas sobre o destino de Marcellino. Havia quem dissesse que foi brutalmente assassinado (e mesmo, segundo uma senhora indígena de Olivença, martirizado, "pregado em uma cruz"). Outros afirmavam que terminou seus dias no Rio de Janeiro; que foi enviado pelo governo para "amansar índios" na Amazônia; ou que virou encantado. 
que o governo federal quisesse. Foi para isto: foi para chantagear, violar todos os direitos. Nós, aqui na Serra, nós falamos assim: "Pode mandar todas que quiserem, nós não vamos recuar um só milímetro". E não recuamos um só milímetro. [...] Nós não negociamos o que nos pertence. Serra do Padeiro não negocia um milímetro, fazendeiro não entra mais aqui. Para entrar, eles vão ter que nos matar, para ocupar qualquer fazenda aqui na Serra. Ou o governo vai ter que construir um presídio, mandar o Exército prender todo mundo, jogar no presídio, para entrar o fazendeiro. Mas no dia em que nós sairmos do presídio, a gente vem cá e bota todos eles para fora de volta. Então não vai resolver, vai ter que matar. Matando, não vai poder tirar, que nós vamos ter que ser enterrados aqui. Então, eles vão botar os caras sobre os cadáveres dos Tupinambás aqui. Não fazemos negociação nenhuma. [...] A Polícia Federal tentou nos matar várias vezes com tiro aqui dentro. Foram muitos tiros. [...] A vida toda atiraram, tentaram nos matar. Nós não recuamos um milímetro. Se não recuamos até hoje, não vamos recuar, nem um milímetro.

\section{DFA - E nesse período vocês tiveram que defender sozinhos o território, inclusive de crimes ambientais, certo?}

CB - Tem alguns crimes contra a natureza, muito graves, que a gente aqui na Serra também enfrentou e impediu totalmente. [...] Que era a retirada ilegal das madeiras aqui, que os rios estavam secando tudo - a gente tinha mais de 60 riachos, e tinham sido reduzidos só a 25. Iam acabar extinguindo os riachos, por causa da retirada ilegal de madeira. Então, nós aqui da Serra do Padeiro fizemos um processo intenso de ocupações e prender caminhão, tomar motosserra, até expulsar esse povo da região. Então, ninguém tira mais madeira aqui desde 2004, que a gente impediu a retirada de madeira aqui da região. $E$ as primeiras retomadas surgiram principalmente por causa do desmatamento, especialmente, que estava acontecendo, e também do tráfico de animais silvestres. Muito. Porque araponga, sabiá-verdadeira, curió, sete-cores, os guris... muito passarinho cantador que nós temos na região, os canários... então era uma violência muito grande o tráfico de animais aqui na região. E também foi outra briga feia que nós tivemos, para expulsar esses traficantes aqui da região. Os caçadores ilegais, que, por esporte, vinham aqui para a região, cheios de arma, matar também. Para nós expulsarmos... então, foi... nós enfrentamos muita gente perigosa até hoje. E daí para cá, esses aí pararam de nos atacar e quem veio atacar foi a polícia.

\section{DFA - Você pode comentar os ataques da polícia?}

CB - Daí para cá... aí, você vem... sucessivos ataques da polícia em cima de nós. Então, nós temos... 2008: vêm umas reintegrações de posse aqui para a Serra. O governo federal, através da Funai, consegue suspender. Mesmo assim, eles mantêm o ataque em 2008 aqui na Serra e usaram cerca de 180 homens, dois helicópteros e 33 veículos, dois rabecões. Foi um ataque de 6 h da manhã até 5 h da tarde, contínuo, sem cessar, aqui na aldeia da Serra do Padeiro. Em 2009, não muito longe, menos de seis meses de um ataque para outro, a Polícia Federal faz um ataque aqui na Santa Rosa [retomada], e tortura cinco índios com choques elétricos. É aquele processo que você já acompanha, estamos processando o governo, por causa desses ataques ${ }^{7}$. Em

7 Trata-se de uma ação civil pública por dano moral coletivo e individual em face da União, proposta pela Procuradoria da República em Ilhéus, em 26 de julho de 2010 (processo nº 1825-23.2010.4.01.3311). 
2010, não muito longe, uns seis meses depois, a polícia... e nesse período aí, a polícia continua atacando coletivamente. A polícia entrar aqui e dar tiro de metralhadora era uma coisa rotineira. [...] Em 2010, lá na Palmeira [Serra das Palmeiras, retomada], exatamente, que é do Alfredo Falcão... esse daí bota uns 22 pistoleiros para tentar nos matar. Foi a Polícia Federal com esse pessoal junto, depois deixaram [os pistoleiros] lá dentro. A gente consegue tirar todos eles. [...] Foi quando também... depois [2010], a Polícia Federal invade minha casa às $2 \mathrm{~h}$ da manhã, faz minha prisão, me leva para o presídio. Prende Gil [Givaldo Ferreira da Silva] depois, meu irmão, manda a gente para Mossoró [Rio Grande do Norte]. Célia [Clicéria Jesus da Silva], minha irmã, vai fazer a denúncia [sobre a violência policial] em Brasília, a Lula. Quando vem, eles fazem uma acusação, então ela é presa. Ficamos nós três presos. Quando eu saio, entro no programa de proteção [Programa de Proteção aos Defensores dos Direitos Humanos, da Secretaria dos Direitos Humanos da Presidência da República - SDH/PR], porque as ameaças de morte são constantes. [...] A revista Época publica, nesse mesmo ano: "trinta mil reais para quem matar o cacique Babau". Está numa reportagem da revista Época. ${ }^{8}[$...] Então esses ataques vêm, continuamente feitos pela polícia. [...] Também, anteriormente um pouco [2008], porque a gente reivindicava o conserto das estradas aqui, a Polícia Federal faz minha prisão. Porque a gente reivindicava direitos, porque eu cobrava do governo do estado que consertasse as estradas, porque iam morrer pessoas, a escola estava parando de funcionar, tudo, por causa do conserto. E aí eu fico também quatro dias preso. Mas depois o governo conserta as estradas. Então, agora, 2011, teve um pouco de calmaria, né? 2012, mais ou menos. Mas a gente sabia que eles estavam tramando, eles estavam apenas se reagrupando, porque eles estavam trabalhando na segura do relatório, para não ser publicado - quer dizer, da portaria declaratória [da $\mathrm{Tl}$ ], que o relatório tinha sido publicado em 2009. [...] Por que nós sofremos esses ataques mortais em 2009 e 2010? Porque a Funai reconheceu o território. Então, para intimidar, os fazendeiros da região, a oligarquia regional usa toda a força militar em cima de nós. [...] Então, nós não recuamos, o relatório se mantém. Aí, quando o relatório vai, é aprovado, vem o contraditório deles [dos indivíduos e grupos contrários à demarcação], também é derrubado pela Funai, eles perdem. Então, só precisava o ministro [da Justiça] publicar. Então, entra outra linha. Eles começaram a deixar tudo calminho e levar cozinhando o ministro para não publicar a portaria declaratória, para não sair. [...] Então, há um complô generalizado contra demarcações de terras indígenas e há um esquema para prender as publicações nas mãos do ministro ou as homologações na mão de Dilma [Rousseff] e não sair. Então, ou seja... um país democrático de verdade não permite uma corrupção nessa altura e violando o direito de vários seres humanos. [...] Então, é bom massacrar índio no país, é bom massacrar Tupinambá, é bom massacrar Guarani, é bom massacrar Terena, é bom massacrar os parentes lá no Tapajós. Entendeu? Os Munduruku. [...] E o governo... há uma cena de ameaça constante, então o governo não assina uma coisa nem outra. Só quem está ferrado é o índio, porque os outros lá tudo estão ganhando. Só quem está ferrado somos nós. Quem está perdendo vida somos nós, índios. [...] [No território tupinambá] Nunca uma prisão por um assassinato de índio, nunca sabe quem é o assassino e nunca foi investigada uma só morte sequer. Me diga: não há um genocídio programado pelo governo? Há. Há um genocídio programado, orquestrado e camuflado pelo próprio governo, porque, no momento em que o governo não resolve o problema, é ele que está sendo o assassino.

8 “No sul da Bahia, diz-se que a cabeça de Babau valeria R\$ 30 mil” (Mariana Sanches, “O Lampião tupinambá", Época, n601. Rio de Janeiro, 21 de novembro de 2009). 
DFA - Como vivem os indígenas que não estão no território? Nós sabemos que muitos dos que perderam suas terras tiveram de ir embora. Alguns voltaram, outros não...

CB - O povo está perdido nas cidades, nas periferias das cidades. [...] Veja bem, você chega ali em Itabuna [município vizinho a Ilhéus], eles estão todos morando na periferia da cidade, nas favelas. É mais grave... eles procuram emprego; como são índios, o povo fala que não quer lidar, nega. Aí, quando acham, não pagam o valor. [...] Outros não têm o que fazer, ficam perambulando, chegam à feira de Itabuna, ali... estão ali pegando caixa, levando bagagem para receber uma gorjeta, um dinheirinho, e totalmente perdidos, totalmente desestruturados, sem família, totalmente, sabe... [...] Há situações muito precárias de todos esses índios que foram parar na periferia das cidades. Quase todos voltam do mesmo jeito. E sempre dizendo que foram muito humilhados, muito humilhados. Então, a discriminação é muito grande na região.

\section{DFA - E como se deram as retomadas?}

$\mathrm{CB}$ - Todas as áreas que estavam sem morador dentro, em que os fazendeiros não viviam, no máximo... em algumas, não tinha ninguém, em outras, tinha meeiros... nós retomamos todas. Então, eu acho que somando tudo está em torno de 70 fazendas ao todo [só na Serra do Padeiro]. [...] Todo mundo trabalhando, que nós temos muito trabalho. [...] Produzimos de tudo, né? Mas o cacau que estava na mão dos fazendeiros não está botando nada. Então a gente precisa recuperar a lavoura cacaueira. Mas aí nós temos muita mandioca, né? Então, todas as famílias têm muita mandioca. A farinha está a um preço bom ainda, então nós temos uma renda considerável ainda. Nós temos a banana também e o abacaxi, que o pessoal tem bastante plantado. O cupuaçu, que você sabe que a gente planta bastante. Então, a renda ainda está boa, graças a deus. Mas tem muito o quê melhorar. [...] Agora que recuperou a organização social nossa, que está integrada, nós vamos ter como fazer investimentos específicos de acordo com a cultura que cada grupo planta. [...] Fome, não passa em Tupinambá.

\section{DFA - Como é a distribuição dos Tupinambá no território hoje?}

CB - Nós, o povo Tupinambá... essa nova composição da terra que a gente reivindicou ficou composta de 22 aldeias. Essas 22 aldeias começam da praia até chegar à Serra do Padeiro. A Serra do Padeiro é a última aldeia, no alto da serra. [...] A Terra Indígena Tupinambá de Olivença foi reconhecida... por que Tupinambá de Olivença? Porque em homenagem ao aldeamento jesuítico Nossa Senhora da Escada, que fica em Olivença. Então, em homenagem ao aldeamento, nós demos o nome do território como Tupinambá de Olivença, oriundo do aldeamento. Ele foi reduzido a um território de 47.376 ha e vivemos com as 22 aldeias dentro.

DFA - Além de as retomadas terem possibilitado o retorno de "parentes" que estavam espalhados mundo afora, o que mais mudou na Serra do Padeiro, desde que elas começaram?

$\mathrm{CB}$ - O rio Una, por exemplo, eles [não-indígenas] jogavam muito veneno e os peixes estavam desaparecendo, os pitus estavam acabando. Agora, pitu, pega 
qualquer hora. Então, recuperou o rio. O rio está repleto de peixe. [...] Na floresta, se você vê a quantidade de curió que nós temos... recuperou totalmente a quantidade de curiós nesses últimos... 2004, que iniciou... dez anos, dez anos. Se você vê, ó. Araponga, a bichinha está fazendo festa por aqui, que estava quase sendo extinta, porque era muito vendável, vendia muito. A sabiá-verdadeira, o mutum voltou. Voltou o macuco. O gavião-real, que tinha desaparecido da região, voltou... que é chamado de harpia, ele é grande, ele dá dois metros de uma asa à outra, ele é bem grandão. Então, voltou. Na serra lá, aquela serra em que nós fomos, tem um casal que já está vivendo lá. Então, todo tipo de bicho aqui: tatu, paca, capivara tem que já está estragando a gente, caititu já exagerou [risos]. A questão de animais e de pássaros... chororão, jacupemba... tudo, tudo voltou. Eles têm... estão em abundância, estão muito felizes, cantando, brincando... [...] Também tem uma espécie de macaco que o pai falou que tinha muito aqui e nós não vimos o retorno dele ainda: foi o macaco-prego. Mas a gente acha que vai voltar. Porque também o tempo é muito curto ainda, a gente acha que eles vão retornar. [...] E os encantados, muito fortes, cada vez mais fortes, fortalecidos, então. Os encantados não somem da natureza.

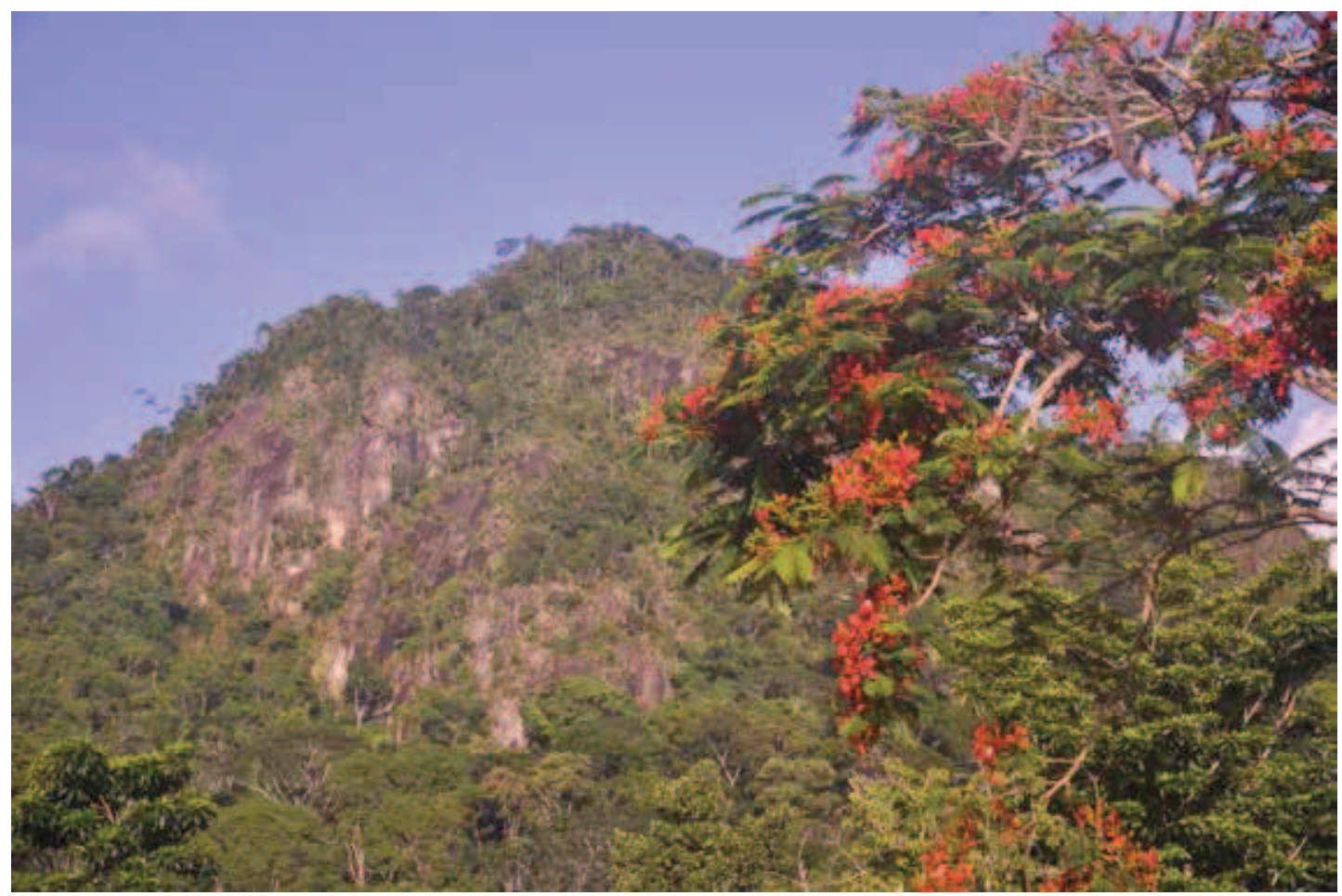

Serra do Padeiro, extremo oeste da Terra Indígena Tupinambá de Olivença; a afloração rochosa é considerada pelos Tupinambá o centro da aldeia homônima.

Por Daniela Alarcon, 7 fev. 2012. 